\title{
Application of zinc oxide nanoparticles as feed additive in broiler chicken nutrition under hot environmental conditions
}

\author{
Hussien, K.R.A., Z.S. H. Ismail and A.A.A. Abdel-Wareth* \\ Department of Animal and Poultry Production, Faculty of Agriculture, South Valley University, 83523-Qena, Egypt
}

\begin{abstract}
Nanotechnology has the potential to use in poultry production with new tools for the enhancing the ability of poultry to absorb nutrients and therefore improving growth performance, nutrient digestibility and productive performance of poultry. The essential trace elements play important roles such as nutrients metabolism, antimicrobial and antioxidant. Numerous studies have already used the effects of zinc sources at lower and higher doses on productive performance of broiler chickens. Most of these studies showed slight positive effects, however significant results were rare. Since there are almost unlimited possibilities concerning levels and sources of zinc there is still more research needed. Using zinc as nanoparticles size can be used at lower doses and can provide better result than the conventional zinc sources. Nanoparticles Zinc oxide can act as antibacterial agent, modulates the immunity and production of broilers. Using of Nanoparticles Zinc oxide in broiler nutrition may support and improve the broiler production. Nevertheless, there is still further studies under more standardized conditions needed to evaluate the optimum dosage as well as the exact mode of action of Nanoparticles Zinc oxide. Therefore, the aim of this study is to give an overview on the potential of nanoparticles of zinc oxide as feed additives in broiler diets, in order to evaluate the optimum dosage and observe their influence on feed intake, growth performance, nutrient digestibility, carcass criteria, and physiological responses.
\end{abstract}

Keywords: Broilers; Nanotechnology; Nutrition; Performances; Zinc.

\section{Introduction}

A high environmental temperature in Upper Egypt is one of the most problems that can causes negatively influence of poultry production. Heat stress can extremely trouble the balance between the generation of reactive oxygen types and the antioxidant system (Tan et al., 2010). The oxidative stress result from heat stress led to an increased radical production, which induces oxidative damage and lipid peroxidation to cellular membranes (Mujahid et al., 2007). This cause physiological changes

\footnotetext{
*Corresponding author: Ahmed A.A. Abdel-Wareth, Email: a.wareth@agr.svu.edu.eg

Received: June 11, 2021; Accepted: June 15, 2021;

Published online: July 30, 2021

CP Published by South Valley University.

This is an open access article licensed under c(i)(이이
}

such as depression of feed intake additionally decreased metabolic heat productive performance (Teeter et al., 1985) and reduce growth rate and feed efficiency (Geraert et al., 1992). Pope (1960) showed that heat stress is responsible for energy intake of broilers and this result in decreased growth rate.

Zinc is an essential microelement which can play an important part in performance, meat quality and carcass traits in broiler (Rajendran et al., 2013). Rao et al. (2016) indicated that male broiler consumed dietary added with $40 \mathrm{mg} / \mathrm{kg}$ $\mathrm{Zn}$ was significantly $(\mathrm{P}<0.05)$ enhancing growth performance and antioxidant responses under heat stress. In addition, Sunder et al. (2008) observed an improvement in immune response 
and mineral retention when broiler fed diet added with zinc. Likewise, both adverse effects of cold and heat stress were decreased in layer fed diet supplemented with zinc and vitamin C (Gerzilov et al., 2015). Thus, under heat stress conditions productive performance was improved in broilers fed diet added with $40 \mathrm{mg}$ Zn /kg (Rao et al., 2016).

Egwurugwu et al. (2013) indicated that the feed supplementation like nanoparticles of minerals can play an active role in productive performance and reproduction system of animals.

Nanoparticles of Zinc oxide is the specially prepared mineral having particle size from 1 to $100 \mathrm{~nm}$ (Swain et al., 2016) it can act as antibacterial, and antioxidant activities and improving broilers performance. The commonly used cereal grains in broilers diets are rich in phytate that may reduce absorption of zinc (Lonnerdal 2000). So that zinc deficiency results in appetite reduction, abnormalities of the skin and growth falling (Brooks et al. 2013; Petrovic et al. 2010). Supplementation of zinc oxide at $100 \mathrm{ppm} / \mathrm{kg}$ diet of male broiler chicks has been significantly enhanced intestinal digestion and nutrients absorption (Ghiasiet et al. 2011). Nanoparticle of zinc oxide at $80 \mathrm{ppm}$ is the best source of zinc when compared to organic and inorganic sources of zinc make better performance and immunity of broilers (Bami et al., 2018). Supplementation of Nanoparticle of zinc oxide to layers diet at 20 to $60 \mathrm{mg} / \mathrm{kg} \mathrm{had}$ been significantly improved nutrient digestibility and enhanced liver and kidney function (Fawaz et al., 2019b).

This study aimed to give an overview on impact of zinc oxide as nanoparticles in broiler chickens diets under upper heat climate conditions, to explore the mode of action of zinc nanoparticles and its effect on broilers performance, nutrient digestibility, and some blood biochemistry.

\section{Mode of action of zinc in poultry nutrition}

Zinc is an important nutrient for animals and humans, which can act as antioxidant, glandular development, poultry performance, protein and carbohydrate metabolism and cofactor in more than 300 metalloenzymes (Salim, 2008). It is essential for enzyme structure, bone development and fast growth (Tüzün, 2018).

Reduced appetite and feed intake is one of the first deficiency of zinc signs observed in poultry by impairing of taste. Chester and Quarterman (1970) indicated that the animal food intake increased within 1-2 hours of zinc supplementation. O’Dell and Reeves (1989) reported that changes in appetite are related to changes in the concentrations of amino acid derived neurotransmitters in the brain. Kennedy et al. (1998) reported that key enzymes required for metabolism of carbohydrate may be lacking because the zinc dependent messenger RNA needed to synthesize these enzymes has reduced expression. Also, high levels of zinc in certain diets may enhance health of poultry independent of its role on the immune system.

Some researchers have demonstrated that zinc supplementation may improve productive performance through a systemic effect via the blood rather than the enteric effects in the small intestine. Fawaz et al. (2019a) indicated that zinc including in dietary can reduce the adverse impact of heat stress. Likewise, both adverse effects of cold and heat stress were decreased in layer fed diet supplemented with zinc and vitamin C (Gerzilov et al., 2015). Thus, under heat stress conditions productive performance was improved in broilers fed diet added with 40 $\mathrm{mg} \mathrm{Zn} \mathrm{/kg} \mathrm{(Rao} \mathrm{et} \mathrm{al.,} \mathrm{2016).} \mathrm{Sunder} \mathrm{et} \mathrm{al.}$ (2008) demonstrated that supplementation of $\mathrm{Zn}$ to broilers diet was important for support immune response and mineral retention. plasma concentration of cortisol, nitric oxide levels and levels of pro-inflammatory were increased by decreased the level of zinc (Chen et al., 2006). 
Dreno et al. (1992) indicated that zinc is a strong anti-inflammatory property because due to its roles in activation of natural killer cells and reducing reactive oxygen species synthesis.

\section{Recommendation levels of zinc in broiler diets}

According to, NRC (1994) recommended 40 $\mathrm{mg} / \mathrm{kg}$ of feed as $\mathrm{Zn}$ requirement of broiler chickens. In recent years, Mohammadi et al. (2015) added different sources of zinc $\mathrm{Zn}$ methionine, $\mathrm{Zn}$-sulphate, nano-Zn sulphate, nano-Zn methionine and zinc-nano max at 80 $\mathrm{mg} / \mathrm{kg}$ broiler diet and indicated that nano- $\mathrm{Zn}$ methionine the best source of zinc to improved performance of broilers. However, Fathi et al. (2016) Supplemented of zinc oxide nanoparticles at 10,20 and $40 \mathrm{mg} / \mathrm{kg}$ to broilers diet and indicated that $20 \mathrm{mg} / \mathrm{kg}$ is the optimal contained of zinc to improved broilers performance and reduced serum concentration of cholesterol. Likewise, Fathi. (2016) who added Nano- $\mathrm{ZnO}$ at 10,20 and $40 \mathrm{mg} / \mathrm{kg}$ to broilers diet and indicated that $20 \mathrm{mg} / \mathrm{kg}$ is the best level of zinc oxide nano particles. Furthermore, Ahmadi et al. (2013) noted that supplementation of $30,60,90$ and $120 \mathrm{mg}$ nano- $\mathrm{ZnO} / \mathrm{kg}$ to broilers diet and the recommended level were 60 from $90 \mathrm{mg} / \mathrm{kg}$ of diet.

\section{Effect of Nanoparticles of Zn Oxide on growth performance of broilers}

Several studies indicated that supplementation of different level and sources of zinc to broilers diets have been improved productive performance. Such as, Rao et al. (2016) reported that supplementation of $40 \mathrm{mg} / \mathrm{kg} \mathrm{Zn}$ to broiler diets significantly $(\mathrm{P}<0.05)$ improved growth performance responses under heat stress. Likewise, Sahin et al. (2005) showed that supplementation of Zinc picolinate at 30 or 60 $\mathrm{mg} / \mathrm{kg} \quad$ significantly improved growth performance of quails exposed to heat stress. In addition, Supplementation of Nanoparticles of $\mathrm{Zn}$ Oxide at $100 \mathrm{mg} / \mathrm{kg}$ to broiler diets significantly improved feed conversion ratio compared to control (Ramiah et al., 2019). Fathi et al. (2016) reported that supplementation of Nanoparticles of Zn Oxide at 10, 20 and 40 $\mathrm{mg} / \mathrm{kg}$ had a significant $(\mathrm{P}<0.001)$ increased feed intake and body weight gain as well as improved feed conversion ratio compared to non-treated broilers. Also, Ahmadi et al. (2013) found that addition of $120 \mathrm{mg} / \mathrm{kg}$ of Nanoparticles of $\mathrm{Zn}$ Oxide to broiler dietary significantly increased $(\mathrm{P}<0.05)$ feed intake. Likewise, Huang et al. (2007) observed that supplementation of $\mathrm{ZnSO} 4$ from 20 up to 140 $\mathrm{mg} / \mathrm{kg}$ were significantly improved daily feed intake compared to control group. However, supplementation of $40 \mathrm{mg}$ Nanoparticles of $\mathrm{Zn}$ Oxide/kg had been not affected feed intake of broiler (Badawi et al., 2017). Also, there was not different in feed intake value when layer fed diet added with $80 \mathrm{mg}$ Nanoparticles of $\mathrm{Zn}$ Oxide/ $\mathrm{kg}$ (Abedini et al., 2017). Thus, feed intake did not affect in Leghorn laying hens received diet supplemented with Nanoparticles of Zn Oxide at $60 \mathrm{mg} / \mathrm{kg}$ (Tsai et al., 2016). In addition, Hafez et al. (2017) noted that supplementation of Nanoparticles of Zn Oxide at 40 and $80 \mathrm{mg} / \mathrm{kg}$ did not influence feed intake. However, Saleh $e t$ al. (2018) observed a significant reduction on feed intake in broilers consumed diet supplemented with zinc methionine at 50 and $100 \mathrm{mg} / \mathrm{kg}$ when compared to control group. Thus, Mohammadi et al. (2015) observed that supplementation of Nanoparticles of $\mathrm{Zn}$ sulphate at $80 \mathrm{mg} / \mathrm{kg}$ had been significantly $(\mathrm{P}<0.01)$ reduced feed intake compared to control group.

Zhao et al. (2014) found that body weight was significantly increased $(\mathrm{P}<0.05)$ in broilers fed diet supplemented with 20 and $60 \mathrm{mg} / \mathrm{kg}$ of nano- $\mathrm{ZnO}$. Chand et al. (2014) found that supplementation of zinc at $60 \mathrm{mg} / \mathrm{kg}$ had been significant increased $(\mathrm{p}<0.05)$ body weight gain and feed intake and improved feed conversion 
ratio of broilers compared to control group. Likewise, Ibrahim et al. (2017) who supplemented $50 \mathrm{mg} / \mathrm{kg}$ from zinc methionine and Nano-ZnO and observed a significant $(\mathrm{P}<0.05)$ increased in body weight gain and feed intake as well as improved feed conversion ratio of broilers compared to control group. In addition, Saleh et al. (2018) indicated that average daily body weight gain, feed conversion ratio and feed intake were significantly improved in broilers fed diet supplemented with zinc methionine at 50 and $100 \mathrm{mg} / \mathrm{kg}$ than that control group. In addition, Hafez et al. (2017) reported that supplementation of Nanoparticles of $\mathrm{Zn}$ Oxide at 40 and $80 \mathrm{mg} / \mathrm{kg}$ to broilers diet significantly improved body weight gain and feed conversion ratio of broilers. However, Mohammadi et al. (2015) observed that supplementation of different sources of zinc $\mathrm{Zn}$ methionine, Zn-sulphate, nano-Zn sulphate, nano-Zn methionine and zinc-nano max at 80 $\mathrm{mg} / \mathrm{kg}$ did not influence feed conversion ratio.

\section{Effect of Nanoparticles of Zn Oxide on nutrient digestibility of broilers}

Dry matter and crud protein digestibility were significantly increased in layer treated with 20 , 40 and $60 \mathrm{mg} / \mathrm{kg}$ compared to control group (Fawaz et al., 2019b). Rao et al. (2016) indicated that male broiler consumed dietary added with $40 \mathrm{mg} / \mathrm{kg} \mathrm{Zn}$ was significantly $(\mathrm{P}<0.05)$ improved nutrient digestibility of crude protein and ether extract under heat stress. Furthermore, ether extract and zinc absorption were significantly $(\mathrm{p}<0.05)$ improved in broilers fed diet supplemented with $50 \mathrm{mg} / \mathrm{kg}$ from zinc methionine or Nano-ZnO compared to control group (Ibrahim et al., 2017). In addition, Saleh et al. (2018) noted that dry matter and crud protein digestibility were significantly higher in broilers fed diet supplemented with zinc methionine at 50 and $100 \mathrm{mg} / \mathrm{kg}$ than that control group. Dry matter, ether extract and crude protein digestibility were linearly increased when Japanese Quail fed diet supplemented with 30 or $60 \mathrm{mg} / \mathrm{kg}$ of zinc sulphate compared to control group (Sahin et al., 2005; Sahin and Kucuk 2003).

\section{Effect of Nanoparticles of Zn Oxide on blood parameters of broilers}

Serum zinc concentration was significantly $(\mathrm{P}<0.01)$ increased in layer fed diet added with $80 \mathrm{mg} / \mathrm{kg}$ when compared to control diet (mao et al., 2017). Also, Idowu et al. (2011) observed that plasma zinc concentration was significantly increased $(\mathrm{P}<0.05)$ in layer fed diet supplemented with $140 \mathrm{mg} / \mathrm{kg}$ of zinc oxide. However, plasma Zn concentration was nonsignificantly affected In layer consumed diet supplemented with supplementation of $80 \mathrm{mg}$ Nanoparticles of $\mathrm{Zn}$ Oxide $/ \mathrm{kg}$ (Abedini et al., 2017).

Ibrahim et al. (2017) found that supplementation of Nanoparticles of $\mathrm{Zn}$ Oxide at $50 \mathrm{mg} / \mathrm{kg}$ to broilers diet did not affected $(\mathrm{P}>0.05)$ serum concentration of aspartate aminotransferase (AST) and Alanine aminotransferase (ALT) compared to control group. However, Fawaz et al. (2019b) indicated that ALT and AST were linearly $(\mathrm{P}<0.001)$ decreased in layers fed diet supplemented with Nanoparticles of Zn Oxide at 20,40 and $60 \mathrm{mg} / \mathrm{kg}$ compared to control group. Likewise, El-katcha et al. (2018) found that serum concentration of AST and ALT activities were significantly $(\mathrm{P}>0.05)$ decreased in layers fed diet supplemented with $30 \mathrm{mg}$ of Nanoparticles of $\mathrm{Zn}$ Oxide/ $\mathrm{kg}$ diet. Serum concentration of aspartate aminotransferase (AST) and Alt were linearly $(\mathrm{P}<0.01)$ decreased in layer consumed graded level of Nanoparticles of $\mathrm{Zn}$ Oxide at 20, 40 and $60 \mathrm{mg} / \mathrm{kg}$ compared to control group (Fawaz et al., 2019b). However, Fathi et al. (2016) Observed that serum activities of ALT, AST was non- significant affect in broilers fed diet added with Nanoparticles of $\mathrm{Zn}$ Oxide at 10, 20 and $40 \mathrm{mg} / \mathrm{kg}$. 
Dietary inclusion of Nanoparticles of $\mathrm{Zn}$ Oxide at 20,40 and $60 \mathrm{mg} / \mathrm{kg}$ quadratically decrease $(\mathrm{p}<0.05)$ serum concentration of creatinine compared to control group (Fawaz et al., 2019b). However, Fathi et al. (2016) indicated that serum concentration of Creatine kinase was non- significantly affected in broilers fed diet added with Nanoparticles of Zn Oxide at 10, 20 and $40 \mathrm{mg} / \mathrm{kg}$.

Serum concentration of total cholesterol was significantly reduced in broilers fed diet supplemented with $50 \mathrm{mg} / \mathrm{kg}$ from zinc methionine or Nanoparticles of $\mathrm{Zn}$ Oxide compared to control group (Ibrahim et al., 2017). Likewise, Zhao et al. (2016) who reported that serum total cholesterol of layer was significantly $(\mathrm{P}<0.05)$ decreased by addition of Nanoparticles of Zn Oxide at 100 and $200 \mathrm{mg}$ per $\mathrm{kg}$ when compared to control group. Thus, Badawi et al. (2017) demonstrated that supplementing $40 \mathrm{ppm}$ Nanoparticles of $\mathrm{Zn}$ Oxide $/ \mathrm{kg}$ to broilers diet did not affect serum concentration of total cholesterol compared with control group. In addition to, Torki et al. (2015) indicated that serum total cholesterol was not affected when layer fed diet supplemented with $40 \mathrm{mg} \mathrm{Zn/kg} \mathrm{diet.}$

Yang et al. (2012) indicated that thyroxine (T4) and estrogen hormone concentrations did not affected in layer fed diet supplemented with 30 $\mathrm{mg} / \mathrm{kg} \mathrm{Zn}$ however, triiodothyronine (T3) was significantly ( $\mathrm{P}<0.005)$ decreased compared with control group.

Mao and Lien (2017) indicated that addition of Nanoparticles of $\mathrm{Zn}$ Oxide at $80 \mathrm{mg} / \mathrm{kg}$ diet significantly increased serum concentration of zinc compared to control group. Thus, Idowu et al. (2011) noted that plasma concentration of zinc was significantly $(\mathrm{P}<0.05)$ higher in layer fed diet with $140 \mathrm{mg} / \mathrm{kg}$ from zinc sulphate, zinc proteinate and zinc carbonate. likewise, Torki et al. (2015) reported that plasma concentration of zinc was significantly $(\mathrm{P}<0.05)$ increased by addition of zinc to broilers diet compared with control group. However, supplementation of 80 $\mathrm{mg} / \mathrm{kg}$ Nanoparticles of $\mathrm{Zn}$ Oxide to hens diet did not changed plasma $\mathrm{Zn}$ concentration (Abedini et al., 2017).

\section{Effect of Nanoparticles of Zn Oxide on carcass criteria and internal organs of broilers}

Relative weight of liver was significantly higher in broilers fed from 30 up to 90 Nanoparticles of $\mathrm{Zn}$ Oxide that than control group however gizzard, pancreas, proventriculus and heart weight were not affected (Ahmadi et al., 2013). Saleh et al. (2018) found a significant reduction on relative weight of abdominal fat in broilers consumed diet addition with zinc methionine at 50 and $100 \mathrm{mg} / \mathrm{kg}$ hsowever, liver weight did not affect when compared to control group. Mohammadi et al. (2015) observed that supplementation of different sources of zinc $\mathrm{Zn}$ methionine, Zn-sulphate, nano-Zn sulphate, Nanoparticles of $\mathrm{Zn}$ methionine and zinc-nano $\max$ at $80 \mathrm{mg} / \mathrm{kg}$ did not influence relative weight of gastrointestinal, heart and liver weight, however, there was a significant reduction on relative weight of abdominal fat in broilers compared control group.

\section{Conclusion}

Generally, it can be concluded that Nanoparticles of Zn Oxide has the potential to be considered as an alternative to other sources and improving productive performance and health status of broiler chickens. Nevertheless, there is still further research under standardized conditions needed to evaluate the exact mechanism of action and to determine the optimal dietary inclusion level in order to optimize meat production, nutrient digestibility and health status of birds. 


\section{References}

Marks, J., (1975) 'A Guide to Vitamins' Medical and Technical Publications, Lancaster, England, pp. 141-143.

Cafantaris, B. (1995) 'Vitamin C: Functions and applicationsin poultry and pigs' Feed Compounder (Jan.):15-20.

Quarles, C. R., and Adrian, W.J. (1988) 'The role of vitaminC in poultry' Page 37 in Stress Management. RCD 7839. Hoffmann-LaRoche Inc., Nutley, NJ.

Volker, L., and Fenster, R. (1991) Pages 42-54 in 8th Eur.Symp. Poult. Nutr. World's Poult. Sci. Assoc., Venezia, Italy.

Kechik, I.T. and Sykes, A.H., (1974) 'Effect of dietary ascorbic acid on the performance of laying hens under warm environmental conditions' British poultry Science, 15: 449-457.

Sahin, K., and Kucuk, O. (2001) 'Effects of vitamin $\mathrm{C}$ andvitamin $\mathrm{E}$ on performance, digestion of nutrients, and carcass characteristics of Japanese quails reared under chronic heat stress $\left(34^{\circ} \mathrm{C}\right)$ ' J. Anim. Physiol. Anim. Nutr. 85:335-342.

Sahin, K. and Sahin, N. (2002) 'Effects of chromium picolinateand ascorbic acid dietary supplementation on nitrogen and mineralexcretion of laying hens reared in a low ambient temperature $\left(7^{\circ} \mathrm{C}\right)^{\prime}$ Acta Vet. Brno. 71:183-189

Sykes, A.H. (1978) 'Vitamin $C$ for poultry -some recent research' Roche Symposium, London, October 1978, pp. 5--15.

Imik, H., O. Kaynar, S. Ozkanlar, R. Gumus, H. Polat, and Y. Ozkanlar. 2013. Effects of vitamin $\mathrm{C}$ and $\alpha$-lipoid acid dietary supplementations on metabolic adaptation of broilers to heat stress. Rev Méd Vét 164:52-59.

Ciftci, M., Ertas, O.N.and Guler, T. (2005) 'Effects of vitamin $\mathrm{E}$ and vitamin $\mathrm{C}$ dietary supplementation on egg production and egg quality of laying hens exposed to a chronic heat stress' Rev. Med. Vet 156 (2):107-111.

McKee, J., and Harrison, P. (1995) 'Effects of supplemental ascorbic acid on the performance of broiler chickens exposed to multiple concurrent stressors' Poultry Science 74 (11):1772-1785.

Niki, E. (1987) 'Interaction of ascorbate and $\alpha$ tocopherol' Annals of the new York Academy of Sciences 498 (1):186-199.

Sahin, K., Sahin, N. and Yaralioglu, S. (2002) 'Effects of vitamin $\mathrm{C}$ and vitamin $\mathrm{E}$ on lipid peroxidation, blood serum metabolites, and mineral concentrations of laying hens reared at high ambient temperature' Biological trace element research 85 (1):35-45.

Mahmoud, K. Z., Edens, F., Eisen, E. and Havenstein. G. (2004) 'Ascorbic acid decreases heat shock protein 70 and plasma corticosterone response in broilers (Gallus gallus domesticus) subjected to cyclic heat stress' Comparative Biochemistry and Physiology Part B: Biochemistry and Molecular Biology 137 (1):35-42.

Panda, A., Ramarao, S., Raju, M. and Chatterjee, R. (2008) 'Effect of dietary supplementation with vitamins $\mathrm{E}$ and $\mathrm{C}$ on production performance, immune responses and antioxidant status of White Leghorn layers under tropical summer conditions' British Poultry Science 49 (5):592-599. 
Sahin K, Kucuk O, Sahin N, Sarı M (2002a) 'Effects of vitamin c and vitamin e on lipid peroxidation status, some serum hormone, metabolite, and mineral concentrations of Japanese quails reared under heat stress $\left(34^{\circ} \mathrm{C}\right)$ ' Int J. Vitam Nutr Res., 72:91-100

Kutlu, H.R. and Forbes, J.M. (1993) 'Changes in growth and blood parameters in heatstressed broiler chicks in response to dietary ascorbic acid' Livest Prod Sci 36:335-350.

Pardue, S.L., Thaxton, J.P. and Brake, J. (1985) 'Influence of supplemental ascorbic acid on broiler performance following exposure to high environmental temperature' Poultry Science 64:13341338

Njokn, P.C. (1984) 'The effect of ascorbic acid supplementation on broiler performance in a tropical environment' Poultry Science 63 (Suppl. 1), 156.

Gan, L., Fan, H., Mahmood, T., and Guo, Y. (2020) 'Dietary supplementation with vitamin $\mathrm{C}$ ameliorates the adverse effects of Salmonella Enteritidis-challenge in broilers by shaping intestinal microbiota' Poultry Science, 99; 3663 - 3674.

Rafiee, F., M. Mazhari, M. Ghoreishi, and O. Esmaeilipour. (2016) 'Effect of lemon verbena powder and vitamin $\mathrm{C}$ on performance and immunity of heatstressed broilers' Journal of Animal Physiology and Animal Nutrition 100 (5):807-812.

Zangeneh, S., Torki, M., Lotfollahian, H. and Abdolmohammadi, A. (2018) 'Effects of dietary supplemental lysophospholipids and vitamin $\mathrm{C}$ on performance, antioxidant enzymes, lipid peroxidation, thyroid hormones and serum metabolites of broiler chickens reared under thermoneutral and high ambient temperature' Journal of Animal Physiology and Animal Nutrition 102 (6):1521-1532.

Lyle, G.R. and Moreng, R.E. (1968) 'Elevated environmental temperature and duration of post-exposure ascorbic acid administration' Poultry Science 47, 410417.

Thornton, P.A. (1961) 'Increased environmental temperature influences on ascorbic acid activity in the domestic fowl' Proceedings of the Federation of American Societies for Experimental Biology 20, 210A

Lohakare, J., Ryu, M., Hahn, T.-W., Lee, J. and Chae, B. (2005) 'Effects of supplemental ascorbic acid on the performance and immunity of commercial broilers' Journal of Applied Poultry Research 14 (1):10-19

Kassim, H. and Norziha, I. (1995) 'Effects of ascorbic acid (vitamin C) supplementation in layer and broiler diets in the tropics' Asian-Australas. Journal Animal Science 8:607-610

Chand, N., Naz, S., Khan, A., Khan, S. and Khan, R.U. (2014) 'Performance traits and immune response of broiler chicks treated with zinc and ascorbic acid supplementation during cyclic heat stress' International Journal of Biometeorology 58 (10):2153-2157.

Abedini, M., Shariatmadari, F., Torshizi, M. K. and Ahmadi, H. (2017) 'Effects of a dietary supplementation with zinc oxide nanoparticles, compared to zinc oxide and zinc methionine, on performance, 
egg quality, and zinc status of laying hens' Livestock Science, 203, 30-36.

Ahmadi, F., Ebrahimnezhad, Y., Sis, N. M. and Ghiasi, J. (2013) 'The effects of zinc oxide nanoparticles on performance, digestive organs and serum lipid concentrations in broiler chickens during starter period' Int J Biosci, 3(7), 23-29.

Badawi, M., Ali, M. and Behairy, A. (2017) 'Effects of zinc sources supplementation on performance of broiler chickens' $J$ Am Sci, 13, 35-40.

Bami, M. K., Afsharmanesh, M., Salarmoini, M. and Tavakoli, H. (2018) 'Effect of zinc oxide nanoparticles and Bacillus coagulans as probiotic on growth, histomorphology of intestine, and immune parameters in broiler chickens' Comparative Clinical Pathology, 27(2), 399-406.

Brooks M.A., Grimes J.L., Lloyd K.E., Verissimo S. and Speers J.W. (2013) 'Bioavailability in chicks of zinc from zinc propionate' J. Appl. Poult. Res., 22(2), 153-159.

Chand, N., Naz, S., Khan, A., Khan, S. and Khan, R.U. (2014) 'Performance traits and immune response of broiler chicks treated with zinc and ascorbic acid supplementation during cyclic heat stress' International Journal of Biometeorology 58 (10):2153-2157.

Chen, W.Q., Cheng, Y.Y., Zhao, X.L., Li, S.T., Hou, Y. and Hong, Y. (2006) 'Effects of zinc on the induction of metallothionein isoforms in hippocampus in stress rats' Experimental Biology and Medicine, 231, 1564-1568.

Chester, J.K. and Quarterman, J. (1970) 'Effects of zinc deficiency on food intake and feeding patterns of rats' British Journal of Nutrition 24:1061.

Dreno, B., Trossaert, M., Boiteau, H.L. and Litoux, P. (1992) 'Zinc salts effects on granulocyte zinc concentration and chemotaxis in acne patients' Acta DermatoVenereologica, 72, 250-252.

Egwurugwu, J., Ifedi, C., Uchefuna, R., Ezeokafor, E. and Alagwu, E. (2013) 'Effects of zinc on male sex hormones and semen quality in rats' Nigerian Journal of Physiological Sciences, 28(1), 17-22.

El-katcha M., Soltan, M.A., Arafa, M.M., ElNaggar, k. and Kawarei, E.R (2018) 'Impact of dietary replacement of inorganic zinc by organic or nano sources on productive performance, immune response and some blood biochemical constituents of laying hens' Alexandria J. of Veterinary Sci., 59, 4859.

Fathi, M., Haydari, M., and Tanha, T. (2016) 'Effects of zinc oxide nanoparticles on antioxidant status, serum enzymes activities, biochemical parameters and performance in broiler chickens' Journal of Livestock Science and Technologies, 4(2), 7-13.

Fawaz, M., Abdel-Wareth, A., Hassan, H. and Südekum, K. (2019b) 'Applications of nanoparticles of zinc oxide on productive performance of laying hens' SVU-International Journal of Agricultural Sciences, 1(1), 34-45.

Fawaz, M., Südekum, K., Hassan, H., and Abdel-Wareth, A. (2019a) 'Effects of nanoparticles of zinc oxide on productive performance of laying hens.a review' SVU-International Journal of Agricultural Sciences, 1(1), 13-20. 
Geraert, P.A., Guillaumin, S. and Leclercq, B. (1992) 'Effect of high ambient temperature on growth, body composition and energy metabolism of genetically lean and fat male chickens' Proceedings of the $19^{\text {th }}$ World Poultry Congress, Vol. 2, pp. 109-110.

Gerzilov, V., Bozakova, N. and Petrov, P. (2015) 'Influence of dietary zinc and vitamin c supplementation on some blood biochemical parameters and egg production in free-range laying hens' Journal of Central European Agriculture. $16,208-218$.

Ghiasi, J., Karamouz, H., Zadeh Adam Nazhad, H., Maheri Sis, N. and Beheshti, R. (2011) 'Effect of different levels of zinc oxide supplement on mucosal lucine aminopeptidase enzyme activity in small intestine of male broiler chicks' Int. J. Anim. Vet. Adv. 3(5), 313-315.

Hafeez, A., Männer, K., Schieder, C. and Zentek, J. (2016) 'Effect of supplementation of phytogenic feed additives (powdered vs. encapsulated) on performance and nutrient digestibility in broiler chickens' Poultry Science. 95, 622-629.

Huang, Y., Lu, L., Luo, X. and Liu, B. (2007) 'An optimal dietary zinc level of broiler chicks fed a corn-soybean meal diet' Poultry science, 86(12), 2582-2589.

Idowu, O., Ajuwon, R., Oso, A. and Akinloye, O. (2011) 'Effects of zinc supplementation on laying performance, serum chemistry and $\mathrm{Zn}$ residue in tibia bone, liver, excreta and egg shell of laying hens' International Journal of Poultry Science, 10(3), 225-230.
Lonnerdal, B. (2000) 'Dietary factors influencing zinc absorption' The Journal of Nutrition. 130, 1378S-1383S.

Mao, S.-Y. and Lien, T.-F. (2017) 'Effects of nanosized zinc oxide and $\gamma$ polyglutamic acid on eggshell quality and serum parameters of aged laying hens' Archives of animal nutrition, 71(5), 373-383.

Mohammadi, V., Ghazanfari, S., MohammadiSangcheshmeh, A. and Nazaran, M. (2015) 'Comparative effects of zinc-nano complexes, zinc-sulphate and zincmethionine on performance in broiler chickens' British poultry Science 56 (4):486-493.

Mujahid, A, Akiba, Y, Warden, C.H. and Toyomizu, M. (2007) 'Sequential changes in superoxide production, anion carriers and substrate oxidation in skeletal muscle mitochondria of heatstressed chickens' FEBS Lett.;581:3461-3467.

NRC [National Research Council]. (1994) 'Nutrient requirements of poultry' 9th revised ed., National Academie Press, Washington, D. C., 155 pp.

O'Dell. B.L. and Reeves, P.G. (1989) 'Zinc status and food intake. In: Zinc in Human Biology' ILSI Press, Washington, DC pp. 173.

Petrovic V., Nollet, L. and Kovac, G. (2010) 'Effect of dietary supplementation of trace elements on the growth performance and their distribution in the breast and thigh muscles depending on the age of broiler chickens' Acta Vet. Brno. 79(2), 203-209. 
Pope, D.L. (1960) 'Nutrition and environmental studies with broilers' Proceedings of the University of Maryland Nutrition Conference for Feed Manufacturers, pp. $48-51$.

Rajendran, D., Thulasi, A., Jash, S., Selvaraju, S. and Rao, S. (2013) 'Synthesis and application of nano minerals in livestock industry' Animal Nutrition and Reproductive Physiology (Recent Concepts). Satish Serial Publishing House, Delhi, p517-530.

Ramiah, S. K., Awad, E.A., Mookiah, S. and Idrus, Z. (2019) 'Effects of zinc oxide nanoparticles on growth performance and concentrations of malondialdehyde, zinc in tissues, and corticosterone in broiler chickens under heat stress conditions' Poultry science. 98 (9):3828-3838.

Rao, S.R., Prakash, B., Raju, M., Panda, A., Kumari, R. and Reddy, E.P.K. (2016) 'Effect of supplementing organic forms of zinc, selenium and chromium on performance, anti-oxidant and immune responses in broiler chicken reared in tropical summer' Biological trace element research, 172(2), 511-520.

Sahin, K., and Kucuk, O. (2003) 'Zinc supplementation alleviates heat stress in laying Japanese quail' The Journal of nutrition. 133 (9):2808-2811.

Sahin, K., Smith, M., Onderci, M., Sahin, N., Gursu, M. and Kucuk, O. (2005) 'Supplementation of zinc from organic or inorganic source improves performance and antioxidant status of heat-distressed quail' Poultry science. 84 (6):882-887.

Saleh, A.A., Ragab, M.M., Ahmed, E.A., Abudabos, A.M. and Ebeid, T.A. (2018) 'Effect of dietary zinc-methionine supplementation on growth performance, nutrient utilization, antioxidative properties and immune response in broiler chickens under high ambient temperature' Journal of Applied Animal Research. 46 (1):820-827.

Salim H., Jo, C. and Lee, B. (2008) 'Zinc in broiler feeding and nutrition' Avian Biology Research 1, 5-18.

Sunder, G. S., Panda, A., Gopinath, N., Rao, S. R., Raju, M., Reddy, M. and Kumar, C. V. (2008) 'Effects of higher levels of zinc supplementation on performance, mineral availability, and immune competence in broiler chickens' Journal of Applied Poultry Research, 17(1), 7986.

Swain, P.S. Somu, B.N., Rao, D.R., Dominic, G. and Selvaraju, S. (2016) 'Nano zinc, an alternative to conventional zinc as animal feed supplement' $A$ review Animal Nutrition. 2, 134-141.

Tan, G.Y., Yang, L., Fu, Y.Q., Feng, J.H. and Zhang, M.H. (2010) 'Effects of different acute high ambient temperatures on function of hepatic mitochondrial respiration, antioxidative enzymes, and oxidative injury in broiler chickens' Poultry Science. 89:115-122.

Teeter, R.G., Smith, M.O., Owens, F.N., Arp, S.C., Sangiah, S. and Breazile, J.E. (1985) 'Chronic heat stress and respiratory alkalosis: occurrence and treatment in broiler chicks' Poultry Science, 64, 1060-1064.

Torki, M., Akbari, M. and Kaviani, K. (2015) 'Single and combined effects of zinc and cinnamon essential oil in diet on productive performance, egg quality traits, and blood parameters of laying 
hens reared under cold stress condition'

International J. of Biometeorology. 59, 1169-1177.

Tsai, Y., Mao, S., Li, M., Huang, J. and Lien, T. (2016) 'Effects of nanosize zinc oxide on zinc retention, eggshell quality, immune response and serum parameters of aged laying hens' Animal Feed Science and Technology. 213, 99-107.

Tsai, Y., Mao, S., Li, M., Huang, J. and Lien, T. (2016) 'Effects of nanosize zinc oxide on zinc retention, eggshell quality, immune response and serum parameters of aged laying hens' Animal feed science and technology, 213, 99-107.

Tüzün, A.E., Olgun, O. and Yildiz, A.Ö. (2018) 'The Effect of High-Level Dietary Supplementation with Different Zinc
Sources on Performance, Eggshell Quality and Bone Characteristics in Layer Quails' In: "Agriculture for Life, Life for Agriculture" Conference Proceedings, pp. 176-182. Sciendo.

Yang, X., Zhong, L., An, X., Zhang, N., Zhang, L., Han, J., Yao, J., Cote, C. and Sun, Y. (2012) 'Effects of diets supplemented with zinc and manganese on performance and related parameters in laying hens' Animal Science Journal. 83, 474-481.

ZHAO, C.-Y., TAN, S.-X., XIAO, X.-Y., QIU, X.-S., PAN, J.-Q. and TANG, Z.-X. (2014) 'Effects of dietary zinc oxide nanoparticles on growth performance and antioxidative status in broilers' Biological Trace Element Research, 160: 361-367. doi:10.1007/s12011-014-0052-2 